\title{
INTERCAMBIO COM A "LATIN AMERICAN STUDIES ASSOCIATION"
}

Em 1973, a "Latin American Studies Association" escolheu entre as Instituicōes brasileiras o Instituto de Estudos Brasileiros como depositário de teses apresentadas em Universidades norte-americanas sobre assuntos brasllelros, em especial, e latino-americanos em geral. Cabe ao IEB a informacão em ambito nacional sobre a existência dessas teses e fornecimento de cópias xerografadas ou microfilmadas (a preço de custo) a Institulçōes interessadas. O IEB recebeu até o presente o total de 81 teses, cujos títulos estão na relaçao que se segue.

\section{Relaç̃o das "dissertacões" que interessam ao Instituto de Estudos Braileiros}

\section{0}

BRUNEAU, Thomas Charles University of Callfornia, Berkeley, 1970 Confllet and change in the Brazillan Catholle Church. 440 p. 71-15,736

COURTEAU, Joanna The University of Wisconsin, 1970 The world view in the novels of Gracillano Ramos. 227 p. $71-3121$

CUNNIFF, Roger Lee The Unlversity of Texas at Austin, 1970 The great drought: northeast Brazll, 1877-1880. 363 p. 72-23-24

SILVA, Sônla da

Iowa State University, 1970 Food practices of familles in a Brazlllan clty. 342 p.

71-7259

DAVIDSON, David Michael

Yale University, 1970 Rivers and empire: the Madelra route and the Incorporation of the Brazllian Far West, 1737-1808. 535 p. $70-25,257$

GOERTZEL, Ted George

Washington Unlversity, 1970 Brazilian student attitudes towards politics and education. 287 p. 70-18,924

HARRISON, WIIllam Frederic

The University of New Mexico, 1970 A struggle for land in colonial Brazll: the private captaincy of Paraiba do Sul, 1533-1753. 301 p. 
LAWS, David Paul

University of Illinois at Urbana-Champaign, 1970 From memory to imagination: José Lins do Rego's Ciclo da cana-de-acúcar. $185 \mathrm{p}$.

71-5163

LOBB, Charles Gary

University of Callfornia, Berkeley, 1970 The historlcal geography of the cattle regions along Brazil's southern frontier. 244 p.

71-9859

PESCATELLO, Ann Marie University or California, Los Angeles, 1970 Both ends of the journey: an historical study of migration and change in Brazll and Portugal, 1889-1914. 513 p.

70-19,884

RACHUM, Ilan

Columbla University, 1970

Nationallsm and revolution in Brazll, 1922-1930. $232 \mathrm{p}$

$71-17,536$

RIDINGS, Eugene Ware

The University of Florida, 1970 The Bahian Commercial Assoclation, 1840-1889: a prescure group in an underdeveloped area. $343 \mathrm{p}$.

$71-24,968$

SECKINGER, Ron Leroy Polities in Mato Grosso, 1821-1851. 298 p.

The University of Florida, 1970 71-24,975

TOLMAN, Jon M.

The Unlversity of New Mexico, 1970 Theme and form in the poetry of Augusto Frederico Schmidt. 352 p. $\quad 71-19,319$

VINCENT, John Stephen The Unlversity of New Mexico, 1970 Jorge Amado: politics and the novel. $455 \mathrm{p}$. 71-9288

WETZLER, Duane Lewis

Tulane Unlversity, 1970

A study of Cecilla Meireles' Romanceiro da Inconfidencia with an annotated English traslation. $277 \mathrm{p}$.

$71-8090$

\section{1}

AAMODT, Agnes Marie

University of Washington, 1971 Enculturation process and the Papago child: an inquiry into the acquisitiom of perspectives on health and healing. $305 \mathrm{p}$.

$72-15,061$

SS

ANזBARO de Halushka, Delina Unlversity of Callfornia, Los Angeles, 197 La narrativa oral em Bolivia: el cuento folclórico. $713 \mathrm{p}$. 71-16,393

AYALA-VALLEJO, Reynaldo Southern Illinols University, 1971 An historical geography or Parras dela Fuente, Coahuila - Mexico, or the changing man-land relationship in Parras de la Fuente, Coahuila - Mexico. 235 p.

$72-5357$

BADEN, Nancy Tucker

Unlversity of Callfornla, Los Angeles, 1971 Jorge Amado: story teller Bahia (a study of narrative technique). $272 \mathrm{p}$.

BASELGa, Edward M.

$72-2721$

BERSON, Theodore MIchael A political blography of Dr. Oswaldo Aranha of Brazil, 1930-1937. 293 p.

New York Unlversity, 1971 
BLANK, Stephnie Bower

The University of Wisconsin, 1971 Social Integration and social Stabillty in a colonial Spanish American city, Caracas (1595-1627). 206 p.

$71-25,712$

BLEDSOE, Robert Lamar

The University of Wisconsin, 1971 The expressionism of Nelson Rodrigues: a revolution in Brazillan drama. $377 \mathrm{p}$. $71-25,464$

BLOUNT, John Allen

Tulane University, 1971 The public heath movement in São Paulo, Brazil. A history of the sanitary service, 1892-1918. 237 p. 72-14,185

BONGERS, Lael Shannon

University of Callfornia, Los Angeles, 1971 A developmental study of time perception and time perspective in three cultural groups: Anglo American, India American and Mexican American. 137 p. 72-2779

BOоTS, wilson Texter

The American University, 1971 Protestant Christianity in Bolivia: mission theory and practice in three mission churches. 352 p.

$72-9168$

BREIDENBACH, Flora Maria Losacco

University of Illinois at Urbana José Lins do Rêgo: Ciclo da Cana e Fogo Morto. 499 p.

Champaign, 1971 $72-12,101$

CAMPBELL, Lyle Richard

University of California, Los Angeles, 1971 Historical linguistics and Quichean linguistic prehistory. 412 p.

72-13,589

CARNEY, Edmund Jeremiah University of Illinois at Urbana-Champalgn, 1971 The short novel in contemporary Latin American literature. 272 p. $72-6882$

CURTIS, Gerald Glen University of New Mexico, 1971 The short stories of Mário de Andrade. 606 p. 72-13,782

DIRKS, Robert Thomas

Case Western Reserve University, 1971 Networks, groups, and local-level politics in an Afro-Caribbean community. 307 p.

72-18,682

ELLIOT, Willian Wiston Soclocultural change in a Pentecostal group: a case study in education and culture of the Church of God in Sonora, Mexico. 271 p. 72-15,517

FOREMAN, Dorothy Zoetta Modernismo in El Mundo (1894-1900).

University of Missourl-Columbia, 1971 $72-10,598$

GONZALEZ, Alfonso

University of Kansas, 1971 Las técnicas narrativas en dos etapas del novomundismo hlspanoamericano. 299 p. 71-27,148

GONZRLES, Raymond Joseph The Latin American dictator in the novel. $420 \mathrm{p}$. 72-11,925

hazera, Lydia de León

The George washington University, 1971 Nacimiento, desarrollo y transformación de la novela de la selva hispanomarelcana. $272 \mathrm{p}$. 71-27,984 
LANDERS, Clifford E.

The University of Florida, 1971 The Uniăo Democratica Nacional in the state of Guanabara: an attitudinal study of party membership. $361 \mathrm{p}$. $72-16,622$

MARTINS, Teresinha Alves Perelra

The University of New Mexico, 1971 Jullo Cortazar, Clarice Lispector e a nova narrativa latino-americana. 271 p. 72-3999

MATTOON, Robert Howard Yale University, 1971 The Companhia Paulista de Estradas de Ferro, 1868-1900: a local railway enterprise in S. Paulo, Brazil. $277 \mathrm{p}$. $72-\mathbf{1 7 , 1 4 2}$

PANG, Eul Soo

University of Callfornia, Berkeley, 1971 The politics of coronelismo in Brazil: the case of Bahia, 1889-1930. 466 p.

$71-827$

SALMEN, Lawrence Fulton

Columbia University, 1971 The Casa de Cômodos of Rlo de Janeiro: a study of the occupants and accommodations of Inner city slums and a comparison of their characteristics with the ravelas. 215 p.

71-23,622

SILVERMAN, Malcom Noel

Univ. of Illinois at Urbana-Champaing, 1971 An examination of the characters in Jorge Amado's Ciclo da Comédia Bahiana. 312 p.

$71-21,229$

SOVEREIGN, Marie Fearing

The University of Texas at Austin, 1971 The poetic contribution of Jorge de Lima to the Brazllian modernist movement. 277 p.

$72-15,836$

STRAUSS, Norman $\mathrm{T}$.

New York Unlversity, 1971 Brazll in the 1870's as seen by American diplomats. 418 p.

72-13.238

\section{3}

BACCHUS, Wilfred Alan

The University of Connecticut, 1973 The political dimension of water resource development: a study of the Brazillan northeast, $1964-1971.1 .170 \mathrm{p}$

$73-24,388$

BARBOSA, TUllo

Purdue University, 1973 A normatlve analysis of land reform measures in the priority area of Rio de Janeiro, Brazll. 547 p.

. 73-28,045

BLUHM, Louis Herbert University of Illinols at Urbana-Champaign, 1973 Some pollution-related attitudes of high school youth in the United States and Brazll. 225 p.

74-11,950

BROWN, Brent Whiting University of Illinols at Urbana-Champaign, 1973 An analysis of the Brazilan municlpal budgetary process: a case study of Porto Alegre, Brazll. 300 p. 73-17,512

CARMAN, Jdlla Ellzabeth Rogers

Rice University, 1973 An urban family in Brazll: a case study of upward social mobility. 297 p. 
CARTWRIGHT, Cecilla Altuna

The University of Wisconsin, 1973 The cangaceiro as a fictional character in the novels of Franklin Távora, Rodolfo Teofllo and José Lins do Rêgo. $226 \mathrm{p}$. 73-30,311

DADD, Christopher Mark

The University of Wisconsin, 1973 Estimating the influence of household size and composition on consumption patterns by adult equivalente scales for urban households in Brazll, 1960-1970. 220 p.

73-20,241

DEATON, Ronny $\mathrm{H}$.

University of Kansas, 1973 The impact of United States private investment, aid, and trade policles toward Brazil during the Alliance for Progress. 274 p. 74-12,549

DEWITT, John Wainwright

The University of Florlda, 1973 Food production and reglonal development in Bahia, Brazil. 259 p. 74-10,043

DTAS, Stello

University of Houston, 1973 A study of Atconian university principles and their influence on higher education reform in Brazilina universities. $183 \mathrm{p}$.

74-11,831

DOERR, William A. Southern Illinols University, 1973 An evaluative study of the relative efflcacy of Portuguese and English captioned filmstrips for teaching agricultural concepts in.

73-23,686

DONALD, Cleveland, Jr.

Cornell University, 1973 Slavery and abolition in Campos, Brazil, 1830-1888. 271 p. 74-6301

ERGUN, Mehmet Turgay

New York Unlversity, 1973 Public administration and development: The theory of "prifracted" society (includes Argentina, Brazil, Mexico, and Venezuela). 177 p. 74-1881

GOEDERT, Wesceslau J.

The University of Wisconsin, 1973 Cation equilibria in solls of Rio Grande do Sul, Brazll. 215 p. 73-21,154

GUERRERO, Solon Joseph

The Ohio State University, 1973 Structural and individual components of change in a Brazllian agricultura situation. $136 \mathrm{p}$. 73-18,89

HARDING, Timothy Fox

Stanford University, 1973 The political history of organlzed labor in Brazil. 690 p. 73-20,481

IGEL, Regina

The University of New Mexico, 1973 $O$ tema da morte na poesia de Cecllia Melrelles. 243 p. 74-20,323

KELLEY, Russell Lyon

The University of New Mexico, 1973 The venezuela senate: a legislative body in the context of development. $291 \mathrm{p}$.

MARCUS, Howard Allen

Yale University, 1973 Provincial goverment in Săo Paulo: The administration of João Teodoro Xavier (1872-1875). 242 p. 73-28,298

NEHMAN, Gerald Ira

The Ohlo State University, 1978 Small farmer credit use in a depressed community of Săo Paulo. 73-26.879 
OLLIVIER, Louls Leon, $\mathrm{Jr}$.

The University of New Mexico, 1973 Syinchrony, amalgamand communion: Erico Verissimo's o Tempo e o Vento as symbolic complex. $224 \mathrm{p}$.

PAGE, Barbara Butler

University or Callfornia, Los Angeles, 1973 Legitimacy and revolution: the cases of Mexico and Brazil 325 p. 74-11,558

PAIXÃO, Lyra

University of Southern California, 1973 A model curriculum for a Brazllian experimental master's degree program in education. $88 \mathrm{p}$.

PEARSON, David Leander

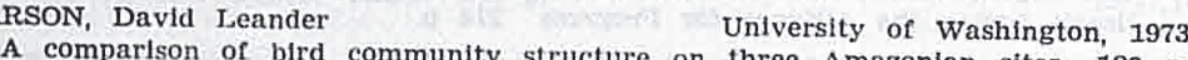

$74-15,586$

PEASE, Stevem Michael

Yale Unlversity, 1973 The spatial agricultural economy: a theoretical study with special reference to Brazil. $191 \mathrm{p}$. 73-29,236

PEDROSO, Iby Arvatti

Resource accumulation The Ohio State University, 1973 Resource accumulation and economies of scale in agriculture: the case of $\mathrm{S}$.
Paulo, Brazil. $128 \mathrm{p}$.

REARWIN, David Ralph

Stanford University, 1973 Archetypal symbols in the poetry of Mário Quintana. $145 \mathrm{p}$.

SALLE DE ALMEIDA, Manoel Ceciliano University of Houston, 1973 A study of the faculty of phllosophy in Brazil: transformation process and the new pattern. $289 \mathrm{p}$.
$74-11,829$

SCHMITT, John Hyde

The University or Wisconsin, 1973 Machado de Assis and the modern Brazllian short story. 211 p. $74-501$

SCHNEIDER, Ivo Alberto

The University of Wisconsin, 1973 Empirical test of the two-step flow hypothesis of communication for new agricultural information in a developing country (Brazil).

73-19,328

SCHOENBACH, Peter Julian

Rutgers University The State University of Modern Brazillan soclal theatre: art and soclal document. $\begin{array}{r}\text { New Jersey, } 1973 \\ 536 \text { p. }\end{array}$

SCHULZ, John Henry

The Brazllian army and pollties, 1850 Princeton University, 1973 The Brazllian army and polltics, $1850-1894.366 \mathrm{p}$.
$73-23,216$

SUPLICY, Eduardo Matarazzo

Michigan State University, 1973 The effects of minidevaluations on the Brazilian economy. 374 p. 74-6147

VIEIRA, David Queirós

The American University, 1973 Prote'*antlsm and the religious question in Brazil: 1850-1875.

WARRIN, Donal Ogden New York University, 1973 Imegem e pensamento na Lira dos Vinte anos. 277 p. $74-13,391$

WHITh, Erdmute Margarete Wenzel The University of Texas at Austin, 1972 O-wald de Andrade et la revolution de lettres au Brésll, 1922-1930. \$38 p. 